Article

\title{
Split Households, Family Migration and Urban Settlement: Findings from China's 2015 National Floating Population Survey
}

\author{
C. Cindy Fan and Tianjiao Li * \\ Department of Geography, University of California-Los Angeles, Los Angeles, 90095-1524 CA, USA; \\ E-Mails: fan@geog.ucla.edu (C.C.F.), tianjiaoli@ucla.edu (T.L.) \\ * Corresponding author
}

Submitted: 18 August 2019 | Accepted: 3 December 2019 | Published: 25 March 2020

\begin{abstract}
For decades, China's rural migrants have split their households between their rural origins and urban work locations. While the hukou system continues to be a barrier to urban settlement, research has also underscored split households as a migrant strategy that spans the rural and urban boundary, questioning if sustained migration will eventually result in permanent urban settlement. Common split-household arrangements include sole migration, where the spouse and children are left behind, and couple migration, where both spouses are migrants, leaving behind their children. More recently, nuclear family migration involving both the spouse and children has been on the rise. Based on a 2015 nationally representative "floating population" survey, this article compares sole migrants, couple migrants, and family migrants in order to examine which migrants choose which household arrangements, including whether specific household arrangements are more associated with settlement intention than others. Our analysis also reveals differences between work-related migrants and family-related migrants. The findings highlight demographic, gender, economic, employment, and destination differences among the different types of migrant household arrangements, pointing to family migration as a likely indicator of permanent settlement. The increase of family migration over time signals to urban governments an increased urgency to address their needs as not only temporary dwellers but more permanent residents.
\end{abstract}

\section{Keywords}

China; family migration; rural-urban migration; settlement; split households

Issue

This article is part of the issue "Boundary Spanning and Reconstitution: Migration, Community and Belonging" edited by Anya Ahmed (University of Salford, UK).

(C) 2020 by the authors; licensee Cogitatio (Lisbon, Portugal). This article is licensed under a Creative Commons Attribution 4.0 International License (CC BY).

\section{Introduction}

Over the past four decades, China has witnessed unprecedentedly speedy urbanization, where the level of urbanization increased from only $18 \%$ in 1978 to $56 \%$ in 2015 (Wu, 2016). Rural-urban migration has been a key driver of this process. Since the 1980s, a prominent feature of China's rural-urban migrants has been their splithousehold arrangement, namely, migrants live and work in urban areas while leaving behind family members in the countryside. Common split-household arrangements include sole migration, where one of the spouses, usually the husband, leaves for migrant work, leaving be- hind the wife and children; and couple migration, where both spouses pursue migrant work without their children. More recently, nuclear family migration where the spouses and their children stay together in the host location has been on the rise, increasing from $41.46 \%$ to $44.96 \%$ of rural-urban migrants from 2011 to 2015 (Fan \& Li, 2019).

Based on a 2015 nationally representative "floating population" survey, this article compares sole migrants, couple migrants, and nuclear family migrants. Our objective is two-fold. First, we aim at describing which migrants tend to choose which household arrangements in order to better understand the phenomenon of split 
households. Second, we would like to shed light on the relationship between household arrangements and the likelihood of permanent settlement, which is of particular interest to policymakers. Section 2 of the article briefly reviews migration theories that are of relevance for split households and permanent settlement. Section 3 focuses on the Chinese context. Sections 4 and 5 are concerned with the data and modeling that constitute our empirical analysis. The concluding section summarizes and discusses our findings.

\section{Split Households and Permanent Settlement}

A split household refers to a situation where family members who under "normal" circumstances would be living in the same place are actually living in separate places. This is contrary to the traditional understanding of a family, which assumes that members of the same family live together most of the time. Migrants all over the world engage in splitting the household, sometimes over a long period of time. Some examples include goldmine workers in South Africa, Mexican braceros in the American Southwest, Chinese laborers in the US in the late 19th century and early 20th century, Hong Kong astronaut families in Canada, transnational households in Afghanistan, and split migrant couples in Kenya (African Population and Health Research Center, 2002; Glenn, 1983; Harpviken, 2014; Kobayashi \& Preston, 2007).

When households are split, migrants may circulate for an extended period of time before settling down permanently, if at all. Zelinsky (1971) defined circulation as "a great variety of movements, usually short-term, repetitive, or cyclical in nature, but all having in common the lack of any declared intention of a permanent or longlasting change in residence." Circular migration and its persistence have been noted in a number of developing countries, prompting a rethinking of the inevitability of permanent migration. Hugo (1982) observed that migrants in Indonesia did not necessarily perceive their mobility as a preliminary stage leading to the ultimate permanent relocation of themselves and their families. Rather, they "exhibit a strong and apparently long-term commitment to bilocality, opting for the combination of activities in both rural and urban areas that a nonpermanent migration strategy allows them" (Hugo, 1982). According to Chapman and Prothero (1983), "rather than being transitional or ephemeral," circulation "is a timehonored and enduring mode of behavior, deeply rooted in a great variety of cultures and found at all stages of socioeconomic change." In this vein, instead of being considered as lacking means and agency towards permanent migration, migrants who engage in circular migration can be seen as pursuing a strategy, one that facilitates their obtaining the best of both worlds by earning in high-income places and spending in low-cost origins (Hugo, 2006). For example, Mexican immigrants to the US can use the farmland in rural Mexico as an economic asset and a basis of household activities (Roberts,
2007). Rather than committing to return or stay, circular migrants are seen as engaging in "migranthood" in order to accumulate migration experience and social and human capital that increase their competitiveness in the urban labor market (Wang, 2007).

From the migrants' point of view, the new economics of labor migration theory explains that, when migrants pursue work elsewhere and leave part of the family behind in their home villages, they can continue to make full use of family resources such as land and housing in the origin, while at the same time access employment opportunities at the destination, thus maximizing income and minimizing risk (Hugo, 1982). From the labor market's perspective, as summarized by the dual labor market theory (Piore, 1979), the low-paid and unstable jobs in the labor-intensive secondary sector fail to attract the local labor force, thereby creating demand for temporary and circular migrants. Given job uncertainty and inferior status in the secondary sector, a split-household strategy helps maintain both economic and social resources in the origin for migrants' possible eventual return.

It is uncertain whether a split household will eventually give way to permanent settlement and family reunification in the host location. Zelinsky's (1971) original mobility transition model predicts that rural-urban migration, and by extension circular migration, is expected to decline as population growth subsides. Skeldon (2010) observed that as urbanization increases, rural-urban circulation as a means to support village life would be replaced by long-term and permanent migration to cities. In South Korea, from 1966 to 1997, the proportion of household heads who migrated for economic reasons decreased from $72 \%$ to $36 \%$, while that for family reasons increased from $6 \%$ to $24 \%$, signaling a rise in family reunification (Schwekendiek, 2016). In China, however, permanent settlement of rural migrants in cities is still uncommon, as discussed in the next section.

\section{Migration, Split Households and Family Migration in China}

Since the 1980s, China has experienced a tremendous increase in population mobility, especially in the form of rural-urban migration. Household-splitting, defined by who migrate(s), for how long, and to where, and who is left behind, constitutes the core of migrants' strategy. Demographer Duan Chengrong has identified four stages of household arrangements (Duan, Lv, \& Zou, 2013). The first stage involves migrants who leave during the farming off-season to work in the city, mostly migrating alone and returning during the farming season. During the second stage, couple migrants pursue work in cities, leaving behind children to be taken care of by grandparents or other relatives. The reunification of the nuclear family constitutes the third stage when couple migrants arrange for their children to join them in the host city. Finally, the fourth stage involves the migration of the extended family. 
Empirical studies have provided support for Duan's framework, at least up to the third stage. During the 1980s, migrant work was regarded as a new means to increase income for rural households, and most migrants were singles (single migration) or married men (sole migration), the latter typically leaving behind wives to shoulder farming and childcare responsibilities (Fan, Sun, \& Zheng, 2011). By the 1990s, migrant work had become even more prevalent, such that "couple migration" where both the husband and wife leave for urban work became increasingly common. According to China's censuses, the percentage of both the household head and the spouse being migrants increased from $7.44 \%$ in 1990 to $46.06 \%$ in 2000 (Duan, Yang, Zhang, \& Lu, 2008). Since the 2000s, the nuclear-family arrangement, where both the spouse and children join migrants in urban areas, has fast gained prominence (Yang \& Chen, 2013). According to the 2011 National Floating Population Dynamic Monitoring Survey (NFPDMS), 47\% of all married rural-urban migrants have reunited with their spouses and children (Yang \& Chen, 2013). What's more, over time, migrant families require fewer batches and shorter batch intervals to reunite (Fan \& Li, 2019).

Despite the increased prevalence of nuclear family migration, it is unclear if rural-urban migrants' likelihood of and intent for permanent settlement in urban areas have also increased. The literature has suggested a number of factors that influence settlement intention: institutional factors, demographic characteristics, marital status and household arrangement, migration experience and work, social factors, housing condition, and destination characteristics (Fan, 2011; Yang \& Guo, 2018; Zhu \& Chen, 2010). Research has shown that migrants are cautious about settlement (Yang, Xu, Liu, Ning, \& Klein, 2016) and that circular migration and the split-household arrangement persist, reflecting migrants' prioritizing economic considerations over family reunification (Ren, 2006). The most common explanation for migrants not settling down in urban areas is the hukou system, which denies and limits rural migrants' access to jobs, health care, education and other social and economic benefits enjoyed by urban Chinese (Chan, Cai, Wan, \& Wang, 2018). Another explanation for split households is that it is a household strategy enabling migrants to take advantage of both origin and destination resources (Fan \& Wang, 2008). In that light, having more family members in the city is not necessarily indicative of a long-term plan towards permanent settlement (Fan, 2011). Whether couple migrants bring the children along may depend on the children's age and whether migrants' parents are available to help, rather than signaling permanent migration (Fan et al., 2011; Li \& Zhang, 2016). However, some studies have indeed found that bringing more family members, especially children, to destination cities helps rural migrants become more integrated into the host society (Wang, Zhang, Ni, Zhang, \& Zhang, 2019).
Over the years, the Chinese government has launched a series of policies and reforms to lower hukou barriers and facilitate rural migrants' settlement in urban areas and by extension their integration into urban society. In particular, the "National Plan on New Urbanization (2014-2020)" aims at providing urban hukou to 100 million rural migrants (The Communist Party of China Central Committee and the State Council, 2014). Nevertheless, local governments, especially those of large cities and megacities, continue to set their own criteria for granting hukou and public services to migrants. While small cities and towns are now more accessible to rural migrants, large cities, whose hukou are much preferred by rural migrants, are still not within reach. In other words, there is a mismatch between hukou reforms and migrants' preference; as a result, rural migrants are reluctant to give up their rural hukou and instead continue to straddle the city and the countryside (Chen \& Fan, 2016).

On the other hand, migrants' behaviors and aspirations may be changing. According to NFPDMS, the percentage of rural migrants who had stayed at the respective destination for more than three years increased from $53.83 \%$ in 2011 to $56.28 \%$ in 2015 respectively, suggesting that rural migrants are staying longer at urban destinations (National Health and Family Planning Commission of the People's Republic of China [NHFPC], 2012 , 2016). Intra-provincial migration, which used to be less voluminous than inter-provincial migration, has increased much more rapidly than inter-provincial migration, such that by 2010 the two volumes were nearly the same (Liu, Qi, \& Cao, 2015). This hints at a greater likelihood of permanent urban settlement, given that short-distance migrants tend to have a stronger intention and ability to permanently settle down in the destination compared to long-distance migrants. In addition, migrant families' motivations may change, especially when they enter different stages of the life cycle. When economic return is no longer the overriding priority of household decision-making, migrants may forgo the economic benefits of migration in order to keep the household intact. For those households, non-economic factors, such as location-specific amenities and children's education, may become more important migration considerations (Chen \& Liu, 2012).

Through a comparison of sole migrants, couple migrants and nuclear family migrants, and considering both migrants who move for work reasons as well as those who move for family reasons, in the empirical analysis that follows we aim at describing the characteristics of migrants that select specific household arrangements, including their likelihood and intention to settle down in urban areas. Given endogeneity in the model, our focus is the statistical association between selected independent variables and migrants' household arrangements rather than causation; and our results are descriptive rather than predictive. 


\section{Data and Definitions}

We employ data from the 2015 NFPDMS. "Floating population" refers to migrants who stay in places different from their hukou locations, the vast majority of whom are rural-urban migrants (NHFPC, 2012, 2016). Piloted in 2009 in just five cities and administered by the National Population and Family Planning Committee, the NFPDMS project was expanded to 31 provinces in 2015. Among publicly available data on the "floating population," these surveys are considered very robust because of their rigorous and random sampling framework, large samples, national coverage, and provincial representativeness.

The 2015 survey has two important features that are especially useful for our research. First, it includes information about household members who are 60 years or older-commonly considered the elderly-who may play a role in household arrangement decisions. Second, compared to past surveys, the 2015 survey has expanded the sample size for each province, thus enabling it to be both nationally representative and provincially representative. The survey has two limitations. First, the information it provides about migrant households' rural resources, such as farmland and rural housing, is limited. Second, the survey does not provide information for the "elderly" who are younger than 60.

The survey defined "floating population" as migrants who had moved across a county (xiàn) boundary from where they were registered and had been in their current location for more than one month. Interviewees must be at least 15 years old. Altogether, the 2015 survey included 193,125 interviewees and 499,406 family members. From the 193,125 interviewees, we arrive at a subset of 58,240 via the following seven steps. In step 1, we select the 137,534 migrants $(71.22 \%)$ whose host location was an urban neighborhood (juweihui) and exclude migrants whose host location was a rural neighborhood (cunweihui). In step 2, we select the 109,853 (79.87\%) migrants who had rural hukou and exclude those with urban hukou. In step 3, we select migrants who were married and were in their first marriage, yielding 85,336 (77.68\%) interviewees. This is because we are interested in couples and not singles (unmarried), and the numbers of remarried, divorced, and widowed are small (less than $4 \%$ in total). In step 4, we keep the 61,930 (72.57\%) interviewees who had at least one child under 16 and exclude those who do not have children or whose children are all over 16 years old. In step 5, we keep the 61,368 (99.09\%) interviewees whose spouse lived in either the host location $(56,991)$ or the home village $(4,377)$ and exclude those whose spouse lived elsewhere. In step 6, we keep the 58,646 (95.57\%) interviewees whose children were either all living in the host location $(43,055)$ or all living in the home village $(15,591)$ and exclude those who had some children in the host location and some in the home village or had children who lived elsewhere.

Finally, step 7 is concerned with migrants' household arrangements. We are especially interested in the role of young children (under 16)-including left-behind and migrant children-in shaping the migrant households and their settlement intention. Based on previous research on split households (Fan et al., 2011), we define sole migrants as those who migrate alone, leaving the spouse and all young children behind at the home village; and couple migrants as spouses who migrate to and reside together at the same host location, leaving all young children behind in the home villages. For simplicity's sake, hereafter we refer to nuclear family migration, where both spouses and all young children reside together at the same host location, as family migration; and the migrants with this arrangement as family migrants. We exclude interviewees who were with their children in the host location without the spouse (i.e., one parent with children) because this arrangement accounted for less than $1 \%$ of the interviewees. The 58,240 interviewees that remain after step 7 constitute our sample for the statistical analysis ( 3,872 sole migrants, 11,719 couple migrants, and 42,649 family migrants).

Before estimating models on household arrangement, one important distinction needs to be made, namely, migrants' reasons for migration. While $86.45 \%$ of the migrants in our sample came to the host location for work, $13.55 \%$ came for family reasons. What's more, these two types of migrants are considerably different (Table 1). While women constitute $93.40 \%$ of familyrelated migrants, they account for only $41.14 \%$ of workrelated migrants, suggesting that the wife is more likely the follower in migration. With regards to migration distance, $46.79 \%$ of work-related migrants are interprovincial migrants, compared to $39.27 \%$ of family-related migrants, suggesting that the latter's moves tend to be of shorter distances. Family-related migrants are younger, with an average age of 30.89 compared to 33.96 for workrelated migrants. The former also have younger children; more than half have pre-school children (under 5 years old) compared to only $35.91 \%$ of work-related migrants.

In rural China, the elderly are often the ones providing care for young left-behind children. About $60 \%$ of work-related migrants and $50 \%$ of family-related migrants have at least one elderly family member at the home village, suggesting that the former have more elderly support than the latter. While more than $90 \%$ of work-related migrants are working, only about $30 \%$ of family-related migrants are, suggesting that the follower migrants, mostly women as observed earlier, tend to join the spouse to help with household chores and caregiving. The high proportion of non-working family-related migrants results in a much lower per capita monthly income (1,166 yuan) than work-related migrants $(4,121$ yuan). Respectively $31.33 \%$ of family-related migrants and $21.85 \%$ of work-related migrants gave birth to their oldest children (under 16) at the host location. This may be a result of the former's relative lack of elderly support in the home village, but may also hint at their greater integration into the host society than work-related migrants. Family-related migrants' host lo- 
Table 1. Migrants by migration reason.

\begin{tabular}{|c|c|c|c|}
\hline \multirow[b]{2}{*}{ Category } & \multirow[b]{2}{*}{ Variables } & \multicolumn{2}{|c|}{ Migration reason } \\
\hline & & Family-related migrants* & Work-related migrants* \\
\hline \multirow{8}{*}{$\begin{array}{l}\text { Individual } \\
\text { factors }\end{array}$} & Gender: Male & $6.60 \%$ & $58.86 \%$ \\
\hline & Female & $93.40 \%$ & $41.14 \%$ \\
\hline & Interviewee's age & 30.89 & 33.96 \\
\hline & Education: Middle school and below & $71.73 \%$ & $70.08 \%$ \\
\hline & High school and above & $28.27 \%$ & $29.92 \%$ \\
\hline & Migration distance: Interprovincial & $39.27 \%$ & $46.79 \%$ \\
\hline & Intercity & $35.49 \%$ & $31.77 \%$ \\
\hline & Intercounty & $25.24 \%$ & $21.44 \%$ \\
\hline \multirow{8}{*}{$\begin{array}{l}\text { Family } \\
\text { characteristics }\end{array}$} & Number of children under 16 & 1.3324 & 1.3391 \\
\hline & Oldest child's age: under 5 & $50.13 \%$ & $35.91 \%$ \\
\hline & $6-11$ & $31.41 \%$ & $37.31 \%$ \\
\hline & $12-16$ & $18.46 \%$ & $26.78 \%$ \\
\hline & $\begin{array}{l}\text { Number of elderly (over } 60 \text { years old) in } \\
\text { home village }\end{array}$ & & \\
\hline & 0 & $49.08 \%$ & $39.58 \%$ \\
\hline & 1 & $13.83 \%$ & $16.96 \%$ \\
\hline & 2 & $37.09 \%$ & $43.46 \%$ \\
\hline \multirow{6}{*}{$\begin{array}{l}\text { Economic } \\
\text { condition }\end{array}$} & Occupation: Non-working & $69.49 \%$ & $9.02 \%$ \\
\hline & Self-employed & $14.93 \%$ & $50.04 \%$ \\
\hline & Employee & $15.58 \%$ & $40.94 \%$ \\
\hline & Monthly income (yuan) & 1165.57 & 4120.63 \\
\hline & Household's monthly income (yuan) & 6258.60 & 6889.15 \\
\hline & Ratio of total expenditure to total income & $63.36 \%$ & $58.06 \%$ \\
\hline \multirow{11}{*}{$\begin{array}{l}\text { Experience at } \\
\text { host location }\end{array}$} & Duration at host location (years) & 4.92 & 4.55 \\
\hline & Birthplace of oldest child under 16 & & \\
\hline & Host location & $31.33 \%$ & $21.85 \%$ \\
\hline & Home village or other places & $68.67 \%$ & $78.15 \%$ \\
\hline & Mother's location during pregnancy & & \\
\hline & Mainly at host location & $48.47 \%$ & $40.45 \%$ \\
\hline & Mainly at home village & $51.53 \%$ & $59.55 \%$ \\
\hline & Settlement intention (for over 5 years) & & \\
\hline & Yes & $65.69 \%$ & $65.66 \%$ \\
\hline & No & $8.29 \%$ & $9.18 \%$ \\
\hline & Undecided & $26.02 \%$ & $25.16 \%$ \\
\hline \multirow{3}{*}{$\begin{array}{l}\text { Regional factors } \\
\text { (host province) }\end{array}$} & GDP per capita (yuan) & 50065 & 51888 \\
\hline & Ratio of teachers to students in primary schools & 0.0648 & 0.0620 \\
\hline & Public green space per capita $\left(\mathrm{m}^{2}\right)$ & 13.08 & 12.96 \\
\hline
\end{tabular}

Notes: Family-related migrants $\left({ }^{*}\right)$ refers to individuals who moved primarily for family or social reasons, including "joining family members," "marriage," "housing change," "seeking help from relatives or friends," and "giving birth;" and work-related migrants refer to individuals who moved for work and employment reasons, including "industry/business," "study/training," and "joining army" (Fan, 2008 , p. 55). "Industry/business" and "joining family members" account for respectively $86.33 \%$ and $11.91 \%$ of all respondents.

cations have higher ratios of primary-school teachers to students and more per capita public green space, while work-related migrants' host locations have higher GDP per capita. These differences suggest that family-related migrants are more concerned with the educational and environmental resources while work-related migrants' focus is more on economic opportunities. In addition, Table 2 shows that nearly $90 \%$ of family-related migrants have a family-migration arrangement, compared to about $71 \%$ of work-related migrants. Given the differences between family-related and work-related migrants observed above, we estimate models for them separately, summarized in the next section.

\section{Modeling}

We have identified five groups of independent variables that might be related to migrants' household arrange- 
Table 2. Household arrangement by migration reason.

\begin{tabular}{lrrrr}
\hline Migration reason & Sole migrants & Couple migrants & Family migrants & All \\
\hline Family-related & $42(0.53 \%)$ & $758(9.61 \%)$ & $7,089(89.86 \%)$ & $7,889(100 \%)$ \\
Work-related & $3,830(7.61 \%)$ & $10,961(21.77 \%)$ & $35,560(70.62 \%)$ & $50,351(100 \%)$ \\
\hline
\end{tabular}

ments (Tables 3 and 4). Individual variables include age, gender, education, and migration distance, similar to Table 1 presented earlier. We use the interaction term of education and gender because the effect of education may be very different between women and men. Migration distance refers to intercity, intercounty, and interprovincial migration, from the shortest to the longest in general. Family variables include the number of children under 16, the age of the oldest child who is under 16 and having at least one elderly (60 or older) in the home village.

Economic condition variables include occupation, monthly income, monthly household income, and the ratio of total household expenditure to total household income. Since the effects of occupation and income may differ between women and men, we use the interaction term with gender for both variables. Host-location experience variables include the birthplace of the oldest child under 16 , the mother's main location during her pregnancy, duration of stay at the host location, and settlement intention measured by willingness to stay in the host location for more than five years. Regional variables include GDP per capita, the ratio of teachers to students in primary schools, and the amount of public green land per capita in the host province.

As mentioned earlier, we are interested in the descriptive, statistical relationship between the independent variables and migrants' household arrangements. Therefore, when interpreting the modeling results, the independent variables may represent both the outcomes of and explanations for the household arrangement.

Among family-related migrants, only 42 interviewees or $0.5 \%$ are sole migrants. Therefore, we have decided to drop them from the modeling and will focus on the differences between couple migrants and family migrants, using logistic regression (Table 3). For the work-related model (Table 4), all three types of household arrangements are included, and multinomial logistic regression is used to test the differences among sole migrants, couple migrants, and family migrants.

\subsection{Family-Related Migrants}

The family-related model is statistically significant, and the Pseudo $R^{2}(0.1680)$ and its correct classification (90.46\%) into couple migrants versus family migrants are reasonable (Table 3 ). We tested multicollinearity by running an ordinary least square regression using the same dependent and independent variables and concluded that correlations among independent variables have not unduly biased the model's estimates.
Among individual variables, only interprovincial migration is statistically significant with a negative coefficient. In other words, couples who migrate over long distances are less likely to bring their children with them. The odds of intercounty migrants being family migrants relative to couple migrants, is about two times that of interprovincial migrants.

Among family variables, the number of children under 16 is positive and significant, suggesting that having more children increases the odds of being family migrants. However, having an oldest child of 6-11 years decreases the odds of being family migrants by about $24 \%$ and having an oldest child of 12-16 years decreases the odds by about $47 \%$. In other words, the older the children, the more likely they are left behind. This is consistent with existing findings of the age distribution of migrant children at destinations: The older the children, the less likely they are brought to cities (Chan et al., 2018).

Education opportunities, governed by government policy and the hukou system, are the key to understanding the age structure of migrant children in cities. Preschool children (under 5 years old) are most likely to be taken to cities by their parents, because they need care and because they are not yet enrolled in schools. The majority of primary-school-age (6-11 years old) children can enroll in public schools, as instructed by the Compulsory Education Law that city governments should provide grades 1-9 education for children of eligible migrants (The National People's Congress Standing Committee, 2006). However, high school education beyond the 9th grade is not mandatory; and local high school admission in many provinces is tied to parents' social security contribution years, which severely constrains migrant children's eligibility (Chen, 2018). Furthermore, the curriculum of high school admission examinations is different in different provinces (Hornby, 2013). Therefore, migrant children usually return to their home location much earlier than grade 9, often as early as grade 6 or 7 , in order to study for local high school admission exams. In other words, while young children accompanying parents to migrate to the host location is feasible or even appealing, it is difficult and generally not desirable for high-school-age or even middleschool-age children to remain in the host location.

Results of economic variables confirm that it is revealing to examine interaction terms between gender on one hand and self-employed, non-working, and monthly income on the other. Female migrants are more likely to be non-working, less likely to be self-employed, and more likely to earn less than male migrants, all of which is consistent with the expected gender division of labor among 
Table 3. Binary logistic regression model for family-related migrants.

\begin{tabular}{|c|c|c|}
\hline \multirow[b]{2}{*}{ Base category: Couple migrants } & \multicolumn{2}{|c|}{ Family migrants } \\
\hline & Coefficient & Odds Ratio \\
\hline \multicolumn{3}{|l|}{ Individual factors } \\
\hline Age & 0.0133 & 1.0134 \\
\hline Gender (ref $=$ male) & -0.2579 & 0.7727 \\
\hline \multicolumn{3}{|l|}{ Education (ref = below high school) } \\
\hline High school and above* Male & -0.4667 & 0.6271 \\
\hline High school and above* Female & -0.0817 & 0.9215 \\
\hline \multicolumn{3}{|l|}{ Distance (ref = intercounty migration) } \\
\hline Intercity & -0.0175 & 0.9310 \\
\hline Interprovincial & $-0.7368 * * *$ & 0.4787 \\
\hline \multicolumn{3}{|l|}{ Family factors } \\
\hline Number of children under 16 & $0.3252 * * *$ & 1.3844 \\
\hline \multicolumn{3}{|l|}{ Age of oldest child (ref $=$ under 5 years) } \\
\hline $6-11$ years old & $-0.2464 * *$ & 0.7616 \\
\hline $12-16$ years old & $-0.6286 * * *$ & 0.5334 \\
\hline Have elderly at 60 or older at home village (ref $=$ no) Yes & -0.0122 & 0.9879 \\
\hline \multicolumn{3}{|l|}{ Economic condition } \\
\hline \multicolumn{3}{|l|}{ Occupation (ref = employee) } \\
\hline Self-employed* Male & 0.0859 & 1.0897 \\
\hline Self-employed* Female & $-0.2733^{* *}$ & 0.7608 \\
\hline Non-working* Male & -0.3608 & 0.6971 \\
\hline Non-working* Female & $0.9364 * * *$ & 2.5507 \\
\hline Interviewee's monthly income* Male & $-2.21 e-5$ & 0.9999 \\
\hline Interviewee's monthly income* Female & $-5.27 e-5^{* * *}$ & 0.9999 \\
\hline Ln (Household's monthly income) & $0.7875 * * *$ & 2.1978 \\
\hline Ratio of total expenditure to total income & $2.2744^{* * *}$ & 9.7223 \\
\hline \multicolumn{3}{|c|}{ Experience at host location } \\
\hline \multicolumn{3}{|c|}{ Birthplace of oldest child under 16 (ref = home village or other places) } \\
\hline Host location & $1.1020^{* * *}$ & 3.0100 \\
\hline \multicolumn{3}{|c|}{ Mother's main location during pregnancy (ref = mainly at home village) } \\
\hline Mainly at host location & 0.0224 & 1.0226 \\
\hline Duration at host location & $0.0341 * * *$ & 1.0346 \\
\hline \multicolumn{3}{|l|}{ Settlement intention ( $r e f=$ no) } \\
\hline Yes & $0.6397 * * *$ & 1.8959 \\
\hline Undecided & $0.3034 * *$ & 1.3545 \\
\hline \multicolumn{3}{|l|}{ Regional factors } \\
\hline GDP per capita & $-1.86 e-06$ & 0.9999 \\
\hline Ratio of teachers to students in primary schools & $42.2538 * * *$ & $2.24 e+18$ \\
\hline Public green space per capita & $0.1011^{* * *}$ & 1.1064 \\
\hline Constant & $-10.9845^{* * *}$ & $1.7 e-5$ \\
\hline Number of observations & 7,844 & \\
\hline LR chi-square & 837.13 & \\
\hline Pseudo $\mathrm{R}^{2}$ & 0.1680 & \\
\hline Percentage correctly classified & $90.46 \%$ & \\
\hline
\end{tabular}

Significance levels: * $0.10 ;{ }^{* *} 0.05 ; * * 0.01$

family migrants, that is, the wife is the family's designated caregiver and she most likely spends much more time than the husband taking care of the children in the host location. At the household level, both monthly income and ratio of total expenditure to total income are positive and significant for family migrants. Despite the wife's weaker earning outcome than the husband, it seems that the latter's earnings more than make up for it. And, not unexpectedly, family migrants spend more than couple migrants due to the former's larger household size at the host location.

The odds of family migrants giving birth to the oldest child at the host location as opposed to the home village are three times more than couple migrants. The location where children are born may signal further settlement intention. In addition, migrants who have stayed at the host location longer are more likely to be family migrants than couple migrants. As for settlement intention, 
migrants who are willing to stay for at least five more years, as well as those who are undecided, are both more likely to be family migrants than couple migrants.

Among regional factors, the ratio of teachers to students and public green space per capita are both positive and significant. In other words, to migrants who move for family reasons, better educational resources and living environment are instrumental to their choosing the arrangement of family migration versus leaving their children behind. To them, the host location is seen as a place to live rather than just a place to make money.

\subsection{Work-Related Migrants}

Table 4 summarizes the multinomial logistic regression model for work-related migrants, where couple migrants

Table 4. Multinominal logistic regression model for work-related migrants.

\begin{tabular}{|c|c|c|c|c|}
\hline \multirow[b]{2}{*}{ Base category: Couple migrants } & \multicolumn{2}{|c|}{ Sole migrants } & \multicolumn{2}{|c|}{ Family migrants } \\
\hline & Coefficient & Odds Ratio & Coefficient & Odds Ratio \\
\hline \multicolumn{5}{|l|}{ Individual factors } \\
\hline Age & 0.0064 & 1.0064 & $0.0098 * * *$ & 1.0099 \\
\hline Gender (ref = male) & $-0.5756 * * *$ & 0.5624 & $-0.1569 * * *$ & 0.8548 \\
\hline \multicolumn{5}{|l|}{ Education (ref = below high school) } \\
\hline High school and above* Male & $0.3124 * * *$ & 1.3667 & 0.0482 & 1.0494 \\
\hline High school and above* Female & $0.5406 * * *$ & 1.7171 & $0.1078 * *$ & 1.1138 \\
\hline \multicolumn{5}{|l|}{ Distance (ref = intercounty migration) } \\
\hline Intercity & $-0.2658 * * *$ & 0.7666 & $-0.1766 * * *$ & 0.8381 \\
\hline Interprovincial & $-0.4708 * * *$ & 0.6245 & $-0.7194 * * *$ & 0.4870 \\
\hline \multicolumn{5}{|l|}{ Family factors } \\
\hline Number of children under 16 & $0.0867 * * *$ & 1.0905 & $0.1285^{* * *}$ & 1.1371 \\
\hline \multicolumn{5}{|l|}{ Age of oldest child (ref $=$ under 5 years) } \\
\hline $6-11$ years old & $-0.1331^{* *}$ & 0.8754 & $0.0754 * *$ & 1.0783 \\
\hline 12-16 years old & $-0.2277^{* * *}$ & 0.7963 & $-0.2424 * * *$ & 0.7847 \\
\hline \multicolumn{5}{|l|}{ Have elderly at 60 or older at home village $($ ref $=$ no) } \\
\hline Yes & $-0.0583 * *$ & 0.9434 & $-0.0658 * * *$ & 0.9364 \\
\hline \multicolumn{5}{|l|}{ Economic condition } \\
\hline \multicolumn{5}{|l|}{ Occupation (ref = employee) } \\
\hline Self-employed* Male & $-0.9479 * * *$ & 0.3876 & $-0.1075 * * *$ & 0.8981 \\
\hline Self-employed* Female & $-0.8417 * * *$ & 0.5941 & $0.1598 * * *$ & 1.1733 \\
\hline Non-working* Male & $-0.4824 * * *$ & 0.6173 & $0.1883^{* *}$ & 1.2072 \\
\hline Non-working* Female & $-0.5207 * * *$ & 0.5941 & $0.6036^{* * *}$ & 1.8286 \\
\hline Interviewee's monthly income* Male & $1.303 \mathrm{e}-4 * * *$ & 1.0001 & $3.52 \mathrm{e}-5^{* * *}$ & 1.0000 \\
\hline Interviewee's monthly income* Female & $1.176 \mathrm{e}-4 * * *$ & 1.0001 & $-5.81 e-06$ & 0.9999 \\
\hline Ln (Household's monthly income) & $-2.0507 * * *$ & 0.1286 & $0.2796 * * *$ & 1.3225 \\
\hline Ratio of total expenditure to total income & $-1.6554 * * *$ & 0.1910 & $1.9538 * * *$ & 7.0554 \\
\hline \multicolumn{5}{|c|}{ Experience at host location } \\
\hline \multicolumn{5}{|c|}{ Birthplace of oldest child under 16 (ref = home village or other places) } \\
\hline Host location & -0.0279 & 0.9724 & $1.3426 * * *$ & 3.8291 \\
\hline \multicolumn{5}{|c|}{ Mother's main location during pregnancy (ref = mainly at home village) } \\
\hline Mainly at host location & $-0.8073 * * *$ & 0.4460 & $0.1537^{* * *}$ & 1.1662 \\
\hline Duration at host location & $-0.0233 * * *$ & 0.9770 & $0.0395 * * *$ & 1.0403 \\
\hline \multicolumn{5}{|l|}{ Settlement intention ( $r e f=$ no) } \\
\hline Yes & $-0.5887^{* * *}$ & 0.5550 & $0.8314 * * *$ & 2.2964 \\
\hline Undecided & $-0.4098 * * *$ & 0.6638 & $0.2330 * * *$ & 1.2624 \\
\hline \multicolumn{5}{|l|}{ Regional factors } \\
\hline GDP per capita & $-3.08 \mathrm{e}-08$ & 1.0000 & $-3.57 e-06 * * *$ & 0.9999 \\
\hline Ratio of teachers to students in primary schools & $-23.9102 * * *$ & $4.13 e-11$ & $31.2198 * * *$ & $3.62 e+13$ \\
\hline Public green space per capita & $-0.0641 * * *$ & 0.9379 & $0.0441 * * *$ & 1.0451 \\
\hline Constant & $20.3817 * * *$ & $7.11 \mathrm{e}+08$ & $-5.7367 * * *$ & 0.0032 \\
\hline Number of observations & 50,329 & & & \\
\hline LR chi-square & 14064.62 & & & \\
\hline Pseudo $\mathrm{R}^{2}$ & 0.1806 & & & \\
\hline Percentage correctly classified & $74.11 \%$ & & & \\
\hline
\end{tabular}

Significance levels: ${ }^{*} 0.10 ;{ }^{* *} 0.05 ;{ }^{* * *} 0.01$ 
are defined as the reference group, to be compared with sole migrants and family migrants. The model is statistically significant, and the Pseudo $R^{2}(0.1806)$ and its correct classification $(74.11 \%)$ are both reasonable. We tested multicollinearity by running an ordinary least square regression using the same dependent and independent variables and concluded that correlations among independent variables have not unduly biased the model's estimates. However, the model did not pass the Independence of Irrelevant Alternatives Test (IIA), which is probably due to the endogeneity of the association between the dependent and independent variables. As mentioned earlier, we are more interested in statistical associations than causation directions, and thus our interpretation of the results is descriptive rather than predictive.

Age is positive and significant for family migrants; that is, older migrants are more likely to be family migrants than couple migrants. Gender is negative and significant for both sole migrants and family migrants; that is, women are more likely to be couple migrants and family migrants than sole migrants, reflecting as expected that sole migration is mostly pursued by men. Education is positive and significant for both male and female sole migrants as well as female family migrants, suggesting that couple migrants are the least educated among the three types of migrants. Intercity and intercountry migrations are both negative and significant for sole migrants and family migrants. In other words, couple migrants travel the farthest.

The number of children under 16 is positive and significant for both sole migrants and family migrants. That is, couple migrants tend to have the least number of children, which is consistent with the expectation that parents desire to be with their children. But the age of children matters. The odds of being sole migrants relative to being couple migrants decrease by about $13 \%$ and $21 \%$ when the oldest child is $6-11$ years old and $12-16$ years old respectively. In other words, having preschoolaged children encourages the sole-migration arrangement, with the spouse (usually the wife) left behind for caregiving. When the children are older, the couplemigration option becomes more viable. Similarly, for family migrants, having the oldest child at $12-16$ years old is negative and significant. As mentioned earlier, children at high-school age tend to return to their home village for the respective curriculum. Having elderlies who are 60 years or older at the home village is negative and significant for both family migrants and sole migrants. In other words, older parents may not be capable of taking care of young children, thus motivating migrants to take their children to the host location rather than leaving them behind. They may also need care themselves, thus making it difficult for couple migration to take place.

Both the coefficients of self-employed and nonworking sole migrants are negative and significant for both men and women, suggesting that a more flexible work arrangement, compared to urban jobs such as fac- tory work and domestic work, is more desirable for couples. Furthermore, a more flexible work arrangement, which facilitates childcare, increases the odds to be family migrants relative to couple migrants. The odds of nonworking women are higher than the odds of non-working men to be family migrants relative to couple migrants, indicating that among family migrants, women are more likely than men to play a caregiving role at the expense of employment and work. Likewise, self-employed is positive and significant for female family migrants but negative and significant for male family migrants, relative to couple migrants, suggesting that, among family migrants, women are more likely than men to pursue more flexible work in order to manage their caregiving responsibility.

Monthly income is positive and significant for both male and female sole migrants. It is not difficult to understand that earning outcome is a priority of sole migrants, being the only person in the city while leaving everyone else behind. Monthly income is also positive and significant for male family migrants, but is not significant for female family migrants, which is consistent with the expectation that female family migrants tend to play a supporting role, including enabling their husbands to increase their earnings. Both household monthly income and the ratio of total expenditure to total income are negative and significant for sole migrants and positive and significant for family migrants. This probably reflects household size: Sole-migrant households have the least people and therefore earn and spend the least, whereas family-migrant households have the most people and hence earn and spend the most.

All the host-location experience variables have positive and significant coefficients for family migrants, while four of the five variables have negative and significant coefficients for sole migrants. The odds of migrants giving birth to the oldest child at the host location being family migrants is about four times that of being couple migrants. A woman who mainly stays at the host location during her pregnancy is more likely to be a family migrant and less likely to be a sole migrant, relative to being a couple migrant. A longer duration at the host location is positively associated with family migrants and negatively associated with sole migrants, relative to couple migrants. Intention to stay and indecision to stay for the next five years are both more likely associated with family migrants and less likely associated with sole migrants than couple migrants. All in all, the above suggests that family migrants are the most integrated at the host location and that sole migrants are the least integrated.

GDP per capita is negative and significant, whereas the ratio of teachers to students, as well as public green space per capita, is positive and significant for family migrants. These results suggest that the decision to bring children to the host location is less a function of economic opportunities and more a matter of educational resources and the living environment. On the contrary, educational opportunities and living environment are negative and significant for sole migrants, further supporting 
the observation that sole migrants primarily consider the host location a place to work rather than a place to live.

\section{Conclusion}

Family migration of rural Chinese to urban areas, involving both the spouse and children, has been on the rise, while split households of other forms still persist. Based on a 2015 nationally representative "floating population" survey, this article compares sole migrants, couple migrants, and family migrants in order to examine which migrants tend to choose specific household arrangements, and to shed light on the relationship between household arrangements and the likelihood of permanent settlement.

First, our modeling identifies the demographic, gender, economic, employment, and host-location differences among different migrant household arrangements. Both sole migrants and family migrants are more likely to have young children who lack intergenerational support at the home village, so they either leave one spouse behind or take the children to the host location. But in both cases, children of high-school age tend to return, reflecting the rigidity of hukou-based high-school curriculum. Husbands are more likely to be sole migrants and employees, and wives among family migrants are more likely to be non-working as they tend to assume caregiving and supporting roles. Couple migrants are the least educated and they travel the longest distance and to host locations with higher GDP per capita, reflecting strong motivations to earn income. Family migrants travel the shortest distance to host locations with better educational resources and environmental quality, signaling the importance of the living environment to them.

Second, our analysis reveals some differences between work-related migration and family-related migration. When deciding whether to take the children to the host location, family-related migrants consider mainly children's need for care, while work-related migrants also consider the availability of support at the home village. And, economic opportunities as well as the cost of living matter more to work-related migrants than to familyrelated migrants.

Finally, our results support the notion that family migration is associated with permanent settlement. Family migrants, compared to sole and couple migrants, are likely to have spent longer duration, children born, and long-term settlement intentions at the host location. They tend to consider urban areas not only as a place to make money but also a place to live.

Crossing the rural-urban boundary as a family may hint at increased integration into the urban community. Having said that, two caveats serve as reminders that rural-urban integration remains an aspiration rather than a reality. First, despite the increased prevalence of family migration, split households continue unabated among rural migrants in China. There is no indication that rural Chinese would give up their rural hukou whole- sale in order to settle down in urban areas (Chen \& Fan, 2016). What has emerged, rather, is rural Chinese buying homes and finding work in nearby towns where permanent settlement is more feasible (Wu \& Zhang, 2018). Second, our data is cross-sectional, which does not fully address the frequent changes in the household arrangement among migrants, many continuing to circulate between the city and countryside. Despite these caveats, our results highlight rural-urban migrants as increasingly long-term dwellers rather than short-term guests for work and underscore the urgency for urban governments to invest in both economic and non-economic opportunities for migrants and their family members, including jobs, housing, and schools.

\section{Acknowledgments}

The authors are grateful to Professor Cao Guangzhong and Professor Liu Tao at Peking University, as well as the China Population and Development Research Centre (CPDRC), for their invaluable assistance in providing access to the data used in this article; to the Chancellor's Office at UCLA for funding that supported this research; and to the anonymous referees for their suggestions that helped improve the paper.

\section{Conflict of Interests}

The authors declare no conflict of interest.

\section{References}

African Population and Health Research Center. (2002). Population and health dynamics in Nairobi's informal settlements: Report of the Nairobi cross-sectional slums survey (NCSS) 2000. Nairobi: African Population and Health Research Center.

Chan, K. W., Cai, F., Wan, G., \& Wang, M. (2018). Urbanization with Chinese characteristics: The hukou system and migration. New York, NY: Routledge.

Chapman, M., \& Prothero, R. M. (1983). Themes on circulation in the Third World. International Migration Review, 17(4), 597-632.

Chen, C., \& Fan, C. C. (2016). China's hukou puzzle: Why don't rural migrants want urban hukou? China Review, 16(3), 9-39.

Chen, W., \& Liu, J. (2012). Renko liudong jiatinghua jiqi yingxiang yinsu-Yi beijingshi weili [Family patterns of the floating population in Beijing]. Renkou Xuekan, 196(6), 3-8. Retrieved from http://rkxk. cbpt.cnki.net/WKE/WebPublication/paperDigest. aspx?paperID=9adbee16-dd1e-4d48-b1a7$70 f 557 c 8 c a 65$

Chen, X. (2018). Suiqian zinv chuzhong biyehou de liuxiang-Yidi zhongkao zhengce yingxiang gaozhong jiaoyu xuanze de shizheng yanjiu [Where do the accompanying children flow after graduating from junior high school?]. Qingnian Yanjiu, 420(3), 12-22. 
Duan, C., Lv, L., \& Zou, X. (2013). Dangqian woguo liudong renkou mianlin de zhuyao wenti he duice: Jiyu 2010 nian diliuci quanguo renkou pucha shuju de fenxi [Major challenges for China's floating population and policy suggestions: An analysis of the 2010 population census data]. Renkou Yanjiu, 37(2), 17-24.

Duan, C., Yang, G., Zhang, F., \& Lu, X. (2008). Gaige kaifang yilai woguo liudong renkou biandong de jiu da qushi [Nine major trends of floating population since the reform and opening-up policy]. Renkou Yanjiu, 32(6), 30-43.

Fan, C. C. (2008). China on the move: Migration, the state, and the household. New York, NY: Routledge.

Fan, C. C. (2011). Settlement intention and split households: Findings from a survey of migrants in Beijing's urban villages. China Review, 11(2), 11-41.

Fan, C. C., \& Li, T. (2019). Familization of rural-urban migration in China: Evidence from the 2011 and 2015 national floating population surveys. Area Development and Policy, 4(2), 134-156.

Fan, C. C., Sun, M., \& Zheng, S. (2011). Migration and split households: A comparison of sole, couple, and family migrants in Beijing, China. Environment and Planning A, 43(9), 2164-2185.

Fan, C. C., \& Wang, W. (2008). The household as security: Strategies of rural-urban migrants in China. In I. Nielsen \& R. Smyth (Eds.), Migration and social protection in China (pp. 205-243). Singapore: World Scientific Press.

Glenn, E. N. (1983). Split household, small producer and dual wage earner: An analysis of Chinese-American family strategies. Journal of Marriage and Family, 45(1), 35-46.

Harpviken, K. B. (2014). Split return: Transnational household strategies in Afghan repatriation. International Migration, 52(6), 57-71.

Hornby, L. (2013, November 8). Human cost of China's hukou system. Financial Times. Retrieved from https://www.ft.com/content/5c38bbd0-46c7-11e39c1b-00144feabdc0

Hugo, G. J. (1982). Circular migration in Indonesia. Population and Development Review, 8(1), 59-83.

Hugo, G. J. (2006). Temporary migration and the labour market in Australia. Australian Geographer, 37(2), 211-231.

Kobayashi, A., \& Preston, V. (2007). Transnationalism through the life course: Hong Kong immigrants in Canada. Asia Pacific Viewpoint, 48(2), 151-167.

Li, D., \& Zhang, C. (2016). Waichu haishi liushou: Nongcun fuqi waichu anpai de jingyan yanjiu [Migrating together or staying behind? An empirical research on household arrangement during rural-urban migration]. Shehuixue Yanjiu, 31(5), 139-163.

Liu, T., Qi, Y., \& Cao, G. (2015). Zhongguo liudong renkou kongjian geju yanbian jizhi ji chengzhenhua xiaoying: Jiyu 2000 he 2010 nian renkou pucha fenxian shuju de fenxi [China's floating population in the 21st century: Uneven landscape, influencing factors, and ef- fects on urbanization]. Dili Xuebao, 70(4), 567-581.

National Health and Family Planning Commission of the People's Republic of China. (2012). Zhongguo liudong renkou fazhan baogao [Report on China's migrant population development 2012]. Beijing: Zhongguo Renkou Chubanshe.

National Health and Family Planning Commission of the People's Republic of China. (2016). Zhongguo liudong renkou fazhan baogao [Report on China's migrant population development 2016]. Beijing: Zhongguo Renkou Chubanshe.

Piore, M. J. (1979). Birds of passage: Migrant labor and industrial societies. Cambridge: Cambridge University Press.

Ren, Y. (2006). "Zhubu chendian" yu "juliu jueding juliu"-Shanghaishi wailai renkou juliu moshi fenxi [Gradual precipitation and residence-induced longterm residence: Analysis on floating population's residence pattern in urban China]. Zhongguo Renkou Kexue, 20(3), 67-72.

Roberts, K. D. (2007). The changing profile of Chinese labor migration. In Z. Zhao \& F. Guo (Eds.), Transition and challenge: China's population at the beginning of the 21st century (pp. 233-250). Oxford: Oxford University Press.

Schwekendiek, D. J. (2016). South Korea: A socioeconomic overview from the past to present. New Brunswick, NJ: Transaction Press.

Skeldon, R. (2010). Managing migration for development: Is circular migration the answer? The Whitehead Journal of Diplomacy and International Relations, 11(1), 21-33.

The Communist Party of China Central Committee and the State Council. (2014, March 16). Guojia xinxing chengzhenhua guihua (2014-2020 nian) [National plan on new urbanization 2014-2020] [Press Release]. Retrieved from http://www.gov.cn/zhengce/ 2014-03/16/content_2640075.htm

The National People's Congress Standing Committee. (2006, June 29). Zhonghua renmin gongheguo yiwu jiaoyufa [Compulsory education law of the People's Republic of China] [Press Release]. Retrieved from http://www.gov.cn/flfg/2006-06/30/content_ 323302.htm

Wang, C., Zhang, C., Ni, J., Zhang, H., \& Zhang, J. (2019). Family migration in China: Do migrant children affect parental settlement intention? Journal of Comparative Economics, 47(2), 416-428.

Wang, G. (2007). Liuxue and yimin: From study to migranthood. In M. Thun $\varnothing$ (Ed.), Beyond Chinatown: New Chinese migration and the global expansion of China (pp. 165-181). Copenhagen: NIAS Press.

Wu, G. (2016, April 20). Government report: China's urbanization level reached $56.1 \%$. CCTV. Retrieved from http://english.cctv.com/2016/04/20/ VIDEEZa3SqThUawYkT0xqL29160420.shtml

Wu, Y., \& Zhang, X. (2018). Chengzhenhua beijingxia nongmin jincheng dingju yiyuan ji yingxiang yinsu 
fenxi [Influencing factors of rural migrants' settlement in the context of urbanization]. Jingjixuejia, 2(2), 88-92.

Yang, C., Xu, W., Liu, Y., Ning, Y., \& Klein, K. K. (2016). Staying in the countryside or moving to the city: The determinants of villagers' urban settlement intentions in China. The China Review, 16(3), 41-68.

Yang, J., \& Chen, C. (2013). Liudong jiating de xianzhuang yu tezheng fenxi [Characteristics of family of migrants at the place of destination]. Renkou Xuekan, 35(5), 48-62.
Yang, S., \& Guo, F. (2018). Breaking the barriers: How urban housing ownership has changed migrants' settlement intentions in China. Urban Studies, 55(16), 3689-3707.

Zelinsky, W. (1971). The hypothesis of the mobility transition. Geographical Review, 61(2), 219-249.

Zhu, Y., \& Chen, W. (2010). The settlement intention of China's floating population in the cities: Recent changes and multifaceted individual-level determinants. Population, Space and Place, 16(4), 253-267.

\section{About the Authors}

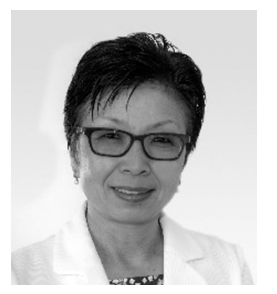

C. Cindy Fan (PhD, Ohio State University, 1989) is a Professor in the Department of Geography at UCLA and is also Vice Provost for International Studies and Global Engagement. She is known for her research on migration, regional development, and gender in China and has published numerous articles. Her book China on the Move: Migration, the State, and the Household (2008, Routledge) is a pioneering study on rural-urban migration and split households in China.

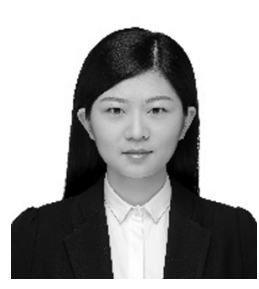

Tianjiao Li obtained her Doctor's degree from Peking University, China, in 2018. Dr. Li was a postdoctoral scholar in the Department of Geography at UCLA from March 2018 to July 2019. She works at the intersections of human geography, sociology, and psychology. Her current research focuses on family migration of the "floating population" and housing outcomes in China. 